\title{
Geography at Cambridge University, England
}

\section{William M. Davis}

To cite this article: William M. Davis (1920) Geography at Cambridge University, England, Journal of Geography, 19:6, 207-210, DOI: 10.1080/00221342008984484

To link to this article: http://dx.doi.org/10.1080/00221342008984484

册 Published online: 13 Feb 2008.

Submit your article to this journal $\pi$

LII Article views: 4

Q View related articles $₫$

4 Citing articles: 1 View citing articles 주다. 


\title{
GEOGRAPHY AT CAMBRIDGE UNIVERSITY, ENGLAND
}

\author{
WILLIAM M. DAVIS
}

Harvard llniversity

According to a report of the Board of Geographical Studies at Cambridge University, a geographical "tripos," or honors degree in geography, has been established there, so that geography now ranks with any other subject, and no longer suffers under the forbidding disabilities that have hampered and discouraged its development for a number of years past at that ancient and renowned seat of learning. The schedule of studies on which examinations will be held is divided into two parts, which may be regarded as introductory and advanced, as follows:

\section{PART I}

1. Physical Geography. (a) The Atmosphere: Distribution of pressure, temperature and humidity; climatic zones and provinces; changes of climate in historic times. (b) The Hydrosphere: Form of the oceans; configuration and depths of the ocean floor; distribution of temperature and silinity; tides; currents. (c) The Lithosphere: Elevation and subsidence; shore-lines; processes of denudation, deposition and vulcanicity, and their effects upon topographical features.

2. Political and Ecomomic Geography. Political partition and economic development of the different regions of the world, with a consideration of the influence of their physical features and economic resources on their settlement, development and lines of communication.

3. Cartography. The construction and use of maps. A general knowledge of the mothods of exploratory surveying, excluding astronomical methods.

Candidates will be expected to submit field work done by themselves and will receive credit for the work submitted.

4. History of Geography. 'The evolution of geographical conceptions; the history of geographical exploration and discovery.

5. Anthropogeography. The classification of the races of mankind, and the physical characters on which it is based. The geographical distribution of races. The influence of geographical environment on the life, arts, social organization, and migrations of certain peoples.

6. Regional Geography. The physical regions of the globe: coastal outline, relief, river systems, climate; influence of physical conditions on economic development.

\section{PART II}

1. Geodetic and Trigonometrical Surveying. Base measurement; triangulation and its adjustment; precise levelling and determination of mean sea level. Topographical surveying. Gravity survey. Delinitation and demarcation of boundaries. Field astronomy.

Candidates will be expected to submit field work done by themselves and will receive credit for the work submitted. 
2. Geomorphology. In addition to the subjects in Part I, $1(c)$, questions may be asked on: Theories to account for the present distribution of land and sea; causes of earth movements; types of earth movement and their distribution; structure and development of the present land masses; distribution of volcanic activity and its relation to earth movements.

3. Oceanography and Climatology. Oceanography [in addition to the subjects in Part I, $1(b)$; methods of observation; physics and chemistry of the sea; marine deposits; distribution of life in the oceans. Climatology [in addition to the subjects in Part 1, 1 (a)]; discussion and reduction of series of observations of different length and value; detection of periodicities; preparation of climatological maps; changes of climate; influence of climate on distribution of animals and plants.

4. Historical and Political Geography. The geographical conditions affecting the historical and political development of States; movements of population and centres of influence; frontiers; colonial expansion; political sub-division for administrative purposes.

5. Economic and Commercial Geography. The geographical conditions affecting the production and distribution of commodities; origin and development of trade routes by land and sea; development of natural resources; growth of industries; exchange of products; development of new regions and sources of trade.

The time given to instruction in the several subjects and the usual duration of a complete course of study at the University leading through the two parts of the schedule are not specified, nor are the members of the committee by which the announcement is issued associated with the special subject that they will teach; but it is evident that any student who commands the subjects here outlined will be, except for the lack of field studies, well on his road to becoming a geographer. The following comments on the schedule are submitted in view of the interest that it must have to American Universities where geography is about to be introduced, or where its present status is to be improved.

One matter of practical importance deserves immediate emphasis. The establishment of the honors degree has not been postponed until the small staff of professional geographers at Cambridge should be duly enlarged. The step has been taken by bringing into geographical service a number of well-known teachers of subjects allied to geography, who will proceed at once to make their contributions as geographical as possible, thus supplementing the work of Lake and Oldham, specialists in physical and historical geography, who represent a more strictly geographical discipline. It is probable that the instruction thus offered will not be so essentially geographical in its nature as if all the teachers were primarily geographers. It will be about as truly geographical as a department of history would be historical if it were made up by drafting in, to assist two instructors in history, several professors of economics, philosophy, geography, classics, and one or two other allied subjects. This is not said in any disparagement of the Cambridge plan, although historians would probably look with 
some dissatisfaction on a department of history thus constituted. The point is that the university proposes to do its geographical best at once, trusting to the future graduates of such instruction-and to geographers trained elsewhere, who may be engaged in the course of time-gradually to develop a more truly geographical discipline. American universities may well do likewise by announcing as soon as possible the best body of geographical instruction that they can put together, enlarging any existing nucleus of professional geographers that they may have in stock by associating with them a number of willing professors from allied departments. The important thing is to make a beginning.

The most gratifying feature of the list of subjects is the importance that is given to the human aspects of geography. 'It is manifest that geography thus broadly treated is not merely an adjunct to geology, but a full-fledged subject, deserving independent recognition. It may be hoped that sooner or later some attention will be given to other forms of life as well as to man, in the expansion of studies to which so broad a beginning must lead in a few decades, and that plants and animals treated for the use of geographers will then be accorded a proper rank.

Another matter of practical importance is the early introduction of political and economic geography, whereby students will be enabled to obtain a general view of these subjects without working through a large preparation in physical geography. This is as if a department of zoology should introduce an early course in the general natural history of animals, treated as a living outdoor subject open to any college student, whether he had already taken or proposed later to take other courses on the structure, embryology, classification, and other subjects of practical importance for zoologists. The object of such a course would be simply to open the students' eyes to the marvelously interesting facts of animal life. The same would be true of a course on political and economic geography treated in a manner suitable for young men and women of university grade. Thus developed, a close association with history and economics may follow, as a result of which the number of students in geography will greatly increase.

The history of geography, including the progress of exploration and discovery, is also an excellent subject for special attention. There is hardly any other that can be made so attractive to a young man of active mind and body, about to make a choice among the many opportunities opened to him in the wide field of university studies. Our universities may do well to make note of this, as one of the best means to impel their graduates to go out and study some part of the world 
for themselves, even if many who do so do not later continue as geographers, but turn to more lucrative occupations.

In certain other respects, the outline of studies does not suggest favorable comment. A curious retention of an old-fashioned, empirical method is seen in both physical geography and regional geography of Part I in the position accorded to shore lines, which are placed before the lands that they border. This is apparently the result of a systematic scheme which begins with the atmosphere, follows with the oceans, and then reaches the lands from the ocean side. No such result is either necessary or advisable. The forms of the lands, as conditioned by "processes of denudation, deposition and vulcanicity," might be given their proper place under (c) the lithosphere; "elevation and subsidence" might follow; then shore lines could be treated rationally, first, as determined by the pattern given to the sea margin when a land mass of previously dissected form or a sea bottom is placed in a new attitude with respect to sea level, and second, as modified by the processes thereafter acting.

Geomorphology in Part II, has a regrettably geological flavor; its highly theoretical topics are likely to divert the student too soon and too far from his more important responsibilities regarding the facts of his science. If more attention to land forms is needed than is indicated under Part I--as may well be the case-geomorphology in Part II might be well replaced by a more advanced consideration of subheading (c), the lithosphere, with particular emphasis on the description of land forms by the student, rather than on the explanation of land forms by the lecturer. Field work might be called for here, and in several other subjects, as well as in cartography and surveying, where it is now alone demanded. Indeed it may be strongly urged that field study of land forms, in association with their verbal description, should precede instruction in topographic surveying, in order to impress upon the student that the thing that he maps is always more important than the map that he makes of it. The regional treatment of physical geography, especially of its subdivisions climatology and land forms, might well be given special attention previous to the regional treatment of geography as a whole, as undertaken in Part I, in order to afford sounder preparation for 4) historical and poltical geography and 5) economic and commercial geography in Part II. 